\title{
HUKUM INTERNASIONAL MADE IN GARUT? MENGKRITISI STATUS JUS COGENS ATAS PRINSIP KEHATI-HATIAN DALAM MANDALAWANGI
}

\author{
AN INTERNATIONAL LAW MADE IN GARUT? CRITICISING JUS COGENS STATUS OF \\ PRECAUTIONARY PRINCIPLE IN \\ MANDALAWANGI
}

\author{
Rizky Banyualam Permanaa, Dewo Baskorob, Arie Afriansyah ${ }^{c}$
}

\begin{abstract}
ABSTRAK
$\mathrm{P}$ utusan Mandalawangi merupakan putusan yang dianggap sebagai suatu terobosan hukum dalam bidang hukum lingkungan di Indonesia, karena putusan ini melakukan inkorporasi atas konsep precautionary principle dalam sistem hukum nasional Indonesia secara legal formal. Jus cogens, yakni suatu norma tidak terelakkan dalam hukum internasional merupakan perdebatan teoritis yang masih berlangsung. Putusan Mandalawangi memberikan status jus cogens atas prinsip kehati-hatian (precautionary principle) kemudian diamini dan diikuti oleh berbagai putusan maupun literatur. Dalam tulisan ini kami mencoba melakukan dekonstruksi kembali tentang status jus cogens atas prinsip kehatihatian, dan kami meninjau bagaimana suatu norma dapat dilabeli sebagai jus cogens dalam teori, serta menelusuri ratio decidendi hakim dalam mencapai amar putusan atas jus cogens. Kami mengargumentasikan bahwa runutan pemikiran putusan tersebut mengandung suatu lompatan logika yang mengakibatkan argumentasi sirkuler. Kemudian kami berpendapat, para hakimlah yang harus mengutamakan 'kehati-hatian' itu sendiri dalam menerapkan konsep-konsep hukum internasional dalam putusannya.
\end{abstract}

Kata kunci: Mandalawangi; jus cogens; prinsip kehati-hatian; Mahkamah Agung.

\begin{abstract}
The judgment of Mandalawangi case is considered as a legal breakthrough in the field of Indonesian 1 environmental law, because the judgment formally incorporated the concept of precautionary principle within the Indonesian domestic legal system. Jus cogens, which is a peremptory norm of international law, is a theoretically controversial subject that is still being debated. Mandalawangi judgment provided the status of jus cogens on precautionary principle which has been followed in the later judgement and decisions. In this article, we attempt to deconstruct the jus cogens status of precautionary principle, and we see how a norm could be labeled as a jus cogens theoretically, as well as retracing the rationale of judges behind the jus cogens status. We argue that the rationale behind the judgment contains a logical jump which causes a circular argument. Following this argument, we stressed that the judges shall employ a precaution in applying the concept of international law through their verdict.
\end{abstract}

Keywords: Mandalawangi; jus cogens; precautionary principle; supreme court.

\footnotetext{
a Center for International Law Studies, Fakultas Hukum Universitas Indonesia, Jl. Prof. mr. Djokosoetono, Kampus UI Depok 16424, email: rizkybanyualam@ui.ac.id.

b Center for Sustainable Ocean Policy, Fakultas Hukum Universitas Indonesia, Jl. Prof. mr. Djokosoetono, Kampus UI Depok 16424, email: ben.debaskoro@gmail.com.

c Bidang Studi Hukum Internasional, Fakultas Hukum Universitas Indonesia, Jl. Prof. mr. Djokosoetono, Kampus UI Depok 16424, email: arie.afriansyah@ui.ac.id.
} 


\section{PENDAHULUAN}

$\mathrm{P}$ utusan Mandalawangi ${ }^{1}$ merupakan putusan yang dianggap sebagai suatu terobosan hukum dalam bidang hukum lingkungan di Indonesia. Meskipun kasus tersebut adalah sengketa perdata, yakni gugatan ganti rugi atas longsor yang terjadi di lembah Mandalawangi, Garut, kasus tersebut menjadi relevan dalam literatur hukum internasional. Hal ini karena dalam putusan tersebut, hakim melakukan inkorporasi atas konsep jus cogens dalam sistem hukum nasional Indonesia secara legal formal. Tidak hanya dari literatur domestik, putusan tersebut telah dirujuk dan dijadikan indikator bahwa, dari perspektif Indonesia, prinsip kehatihatian dipandang sebagai jus cogens oleh literatur di luar Indonesia. ${ }^{2}$

Terdapat beberapa literatur yang membahas tentang pengakuan prinsip kehati-hatian sebagai jus cogens. ${ }^{3}$ Misalnya, Hardjaloka ${ }^{4}$ menerima pandangan hakim tersebut secara utuh, dan menerima analisis hakim tersebut. ${ }^{5}$ Berbeda dengan Hardjaloka, Wibisana menyayangkan absennya penjelasan atau bukti dari status jus cogens atas precautionary principle dalam putusan Mandalawangi. ${ }^{6}$ Absennya analisis hakim dalam Mandalawangi menjadikan argumen prinsip kehati-hatian sebagai jus cogens menjadi argumen sirkuler. Yakni, bahwa karena Mahkamah Agung telah secara serta merta dan sepihak mengakui prinsip kehati-hatian sebagai jus cogens, putusan tersebut kemudian dirujuk untuk membuktikan adanya prinsip kehati-hatian sebagai jus cogens. Sebagaimana diketahui, putusan pengadilan merupakan alat subsider (subsidiary means) untuk menunjukkan eksistensi suatu norma hukum internasional. ${ }^{7}$ Dengan adanya lompatan analisis oleh Mahkamah Agung dalam putusan Mandalawangi, hal ini menimbulkan

\footnotetext{
1 Putusan Mahkamah Agung Nomor 1794K/PDT/2004 Tahun 2004, Direksi Perum. Perhutani cq. Kepala Unit Perum. Perhutani Unit III Jawa Barat; Pemerintah Daerah Tk. I Propinsi Jawa Barat cq. Gubernur Propinsi Jawa Barat et.al vs. Dedi; Hayati et.al. Untuk selanjutnya, dalam tulisan ini putusan ini akan dirujuk dengan Mandalawangi. Lihat: Mahkamah Agung, Putusan Mahkamah Agung Nomor 1794K/PDT/2004

2 Leslie-Anne Duvic-Pavoli, 2019, "Environmental Law and Public International Law," dalam Oxford Handbook of Comparative Environmental Law, eds. Emma Lees, Jorge E. Vinuales, OUP, hlm. 1183

3 Helmi, et. al. "Documenting Land-combustion and Progressive Law Enforcement in Indonesia," Library Philosophy and Practice 2019, hlm. 8; Imamulhadi, "Perkembangan Prinsip Strict Liability dan Precautionary dalam Penyelesaian Sengketa Lingkungan Hidup di Pengadilan" 25 3, Mimbar Hukum 2013, hlm. 427; Andri Wibisana, "The Development of the Precautionary Principle in International and in Indonesian Environmental Law" 141 \& 2, Asia Pacific Journal of Environmental Law 2011, hlm. 18.

4 Loura Hardjaloka, 2012, “Ketepatan Hakim dalam Penerapan Precautionary Principle sebagai “Ius Cogen” dalam Kasus Gunung Mandalawangi" 5 2, Jurnal Yudisial, hlm. 134-153

5 "[...] pertimbangan hakim sudahlah benar, di mana memang Precautionary Principle dapat diterapkan dalam kasus ini. [...] sebagaimana dikatakan oleh hakim Precautionary Principle ini telah dipandang sebagai "ius cogen" [sic!], yaitu sebagai suatu norma yang diterima dan diakui oleh masyarakat internasional secara keseluruhan dan hanya dapat diubah oleh suatu norma dasar hukum internasional umum yang baru yang mempunyai sifat yang sama." Lihat: Ibid., hlm. 151.

6 Wibisana menyatakan bahwa, "Unfortunately, the Supreme Court did not provide further explanation or proof indicating that the precautionary principle has indeed gained such a status. Nor did the Court explain of what it meant by 'jus cogens'." Lihat: Wibisana, catatan kaki no. 3.

7 Pasal 38 ayat (1) Statuta Mahkamah Internasional.
} 
pertanyaan fundamental tentang apakah determinasi prinsip kehati-hatian sebagai jus cogens tersebut sudah tepat? Meskipun putusan Mandalawangi telah lama dijatuhkan, kami beranggapan bahwa perlu kiranya untuk menghentikan langkah sejenak dan merefleksikan kembali konsep-konsep hukum internasional yang terdapat dalam literatur dan putusan pengadilan nasional. Tulisan ini akan mencoba menjawab dua set tingkatan pertanyaan: Pertama, bagaimanakah jus cogens dipahami secara teoritis, yakni bagaimanakah serta siapakah yang dapat menentukan suatu norma menjadi bagian jus cogens atau bukan? Kedua, apakah analisis dan penerapan hukum dan konsep hukum hakim atas jus cogens sudah tepat dari segi teori tentang jus cogens?

Untuk menjawab permasalahan di atas, tulisan ini akan dibagi menjadi enam bagian utama. Bagian kedua akan membahas ulang putusan Mandalawangi. Kemudian pada bagian ketiga, kami menjelaskan tentang perkembangan konsep precautionary principle dan perdebatan yang ada, yang dilanjutkan dengan pembahasan jus cogens pada bagian keempat. Di bagian kelima kami akan melakukan analisis ulang atas rasio hakim atas Mandalawangi. Tulisan ini tidak dimaksudkan untuk membantah maupun mengecilkan pentingnya penerapan prinsip kehati-hatian dalam perlindungan lingkungan, namun demikian penerapan konsep hukum internasional harus sejalan dengan landasan doktrin yang ada.

\section{PEMBAHASAN}

\section{Mengunjungi Mandalawangi 17 Tahun Kemudian}

$\mathrm{T}$

itik perdebatan teoritis tentang penggunaan precautionary principle berasal dari suatu bencana yang menimpa masyarakat Garut. Pada 28 Januari 2003, terjadi bencana longsor di gunung Mandalawangi, Garut yang menewaskan 20 nyawa, satu hilang, rusaknya pemukiman penduduk, dan putusnya jalur transportasi antara Bandung dengan Garut. ${ }^{8}$ Perum Perhutani, melakukan aktivitas pengelolaan kawasan hutan yang berakibat pada pengurangan daya dukung lingkungan dan kerusakan daya serap tanah, yang pada akhirnya menyebabkan longsor. Gugatan class action melawan Perhutani diajukan oleh kelompok terdiri atas korban longsor dan menggugat Direksi Perhutani karena adanya perbuatan melawan hukum yang dilakukan oleh Perhutani. ${ }^{9}$ Menurut Pasal 1365 BW ${ }^{10}$ perbuatan melawan hukum

\footnotetext{
8 Pengadilan Negeri Bandung, Putusan Nomor 49/Pdt.G/2003/PN.Bdg hlm. 6

9 Ibid, hlm. 1.

10“Tiap perbuatan melanggar hukum, yang membawa kerugian kepada seorang lain, mewajibkan orang yang karena salahnya menerbitkan kerugian itu, mengganti kerugian tersebut." Pasal 1365, Burgerlijk Wetboek voor Indonesië (Kitab Undang-undang Hukum Perdata).
} 
harus memenuhi unsur kesalahan, kerugian, serta unsur kausalitas antara kesalahan dan kerugian. Sementara, gugatan tersebut menyatakan bahwa bahkan tanpa unsur kesalahan dari tergugat, longsor yang terjadi merupakan akibat dari perbuatan tergugat. ${ }^{11}$ Dalam hal ini penggugat menggunakan dalil strict liability ${ }^{12}$ sebagai dasar pertanggungjawaban tergugat. ${ }^{13}$ Konsekuensinya adalah penggugat tidak perlu adanya unsur kesalahan dari Perhutani untuk dapat dikatakan melakukan perbuatan melawan hukum.

Akan tetapi, untuk mengartikulasikan dan membantah konsep strict liability dalam perkara bukanlah hal mudah karena masing-masing pihak memiliki pembuktian ilmiah untuk mendukung argumennya masing-masing. ${ }^{14} \mathrm{Di}$ tengah adanya dua dasar ilmiah yang bertentangan, untuk menentukan apakah tergugat bertanggung jawab berdasarkan prinsip strict liability, Majelis Hakim tingkat pertama memutuskan untuk menerapkan prinsip precautionary principle sebagaimana dinyatakan dalam Deklarasi Rio 1992. ${ }^{15}$ Kemudian, menurut Majelis Hakim PN Bandung, meskipun prinsip tersebut belum dimasukkan ke dalam kaidah hukum nasional, 'semangat' dari prinsip ini dapat dipedomani untuk mengisi kekosongan hukum dan praktik karena Indonesia merupakan anggota dari konferensi tersebut. ${ }^{16}$ Kemudian, menurut hakim, precautionary principle diterapkan dalam kasus ini karena sengketa terjadi post factum rusaknya lingkungan, kekurangan pengetahuan tersebut tidak dapat dijadikan alasan untuk menunda upaya-upaya pemulihan terhadap lingkungan yang rusak. ${ }^{17}$ Meskipun sejalan dengan prinsip ke-15 Rio Declaration, di tingkat pertama, Majelis Hakim tidak melakukan analisis atas status hukum dari prinsip tersebut. Prinsip tersebut diterima karena sejalan dan dibaca bersama dengan kaidah hukum yang baik dalam UU No. 23/1997; UU No. 41/1999; 18 dan semangat Pemerintah dalam turut serta pada konferensi PBB yang menghasilkan Rio Declaration. Dengan demikian, hakim melakukan

\footnotetext{
11 Pengadilan Negeri Bandung, Putusan Nomor 49/Pdt.G/2003/PN.Bdg, hlm. 3.

12 Pada saat putusan, pengertian strict liability (tanggung jawab mutlak) yang dimaksud mengacu kepada Undang Undang Undang Nomor 23 Tahun 1997 tentang Pengelolaan Lingkungan Hidup, di mana Penanggung jawab usaha dan/atau kegiatan yang usaha dan kegiatannya menimbulkan dampak besar dan penting terhadap lingkungan hidup, yang menggunakan bahan berbahaya dan beracun, dan/atau menghasilkan limbah bahan berbahaya dan beracun, bertanggung jawab secara mutlak atas kerugian yang ditimbulkan, dengan kewajiban membayar ganti rugi secara langsung dan seketika pada saat terjadinya pencemaran dan/atau perusakan lingkungan hidup. Lihat: Indonesia, Undang Undang Undang Nomor 23 Tahun 1997 tentang Pengelolaan Lingkungan Hidup, Pasal 35 ayat (1).

${ }_{13}$ Pengadilan Negeri Bandung, Putusan Nomor 49/Pdt.G/2003/PN.Bdg, hlm. 9

14 Para pihak yang bersengketa berbeda mengenai titik longsor, kondisi geologis dan curah hujan, sehingga terdapat perbedaan pendapat tentang penyebab pasti longsor tersebut.

${ }_{15}$ Pengadilan Negeri Bandung, Putusan Nomor 49/Pdt.G/2003/PN.Bdg, hlm. 74.

${ }^{16}$ Ibid, hlm. 101.

${ }^{17} \mathrm{Ibid} .$, hlm. 102.

18 Ibid.
} 
konstruksi hukum bahwa pertanggungjawaban berdasarkan kesalahan (fault-based liability) sebagaimana diatur dalam Pasal 1365 BW menjadi tidak relevan, serta atas dasar tersebut berlaku strict liability bagi tindakan Perhutani dkk. Putusan PN Bandung tersebut dibanding oleh tergugat, tetapi Pengadilan Tinggi Bandung kemudian membenarkan penerapan hukum PN Bandung tanpa adanya analisis lebih lanjut. ${ }^{19}$

Akan tetapi, penggunaan precautionary principle sebagai dasar bagi hakim untuk menerapkan strict liability inilah yang kemudian dipermasalahkan di tingkat Kasasi. ${ }^{20}$ Di dalam Putusan Mahkamah Agung Nomor 1794/Pdt/2004, Majelis Hakim menyatakan:

Bahwa Hakim tidak salah menerapkan hukum apabila ia mengadopsi ketentuan hukum internasional. Penerapan precautionary principle di dalam [sic!] hukum lingkungan hidup adalah untuk mengisi kekosongan hukum (Rechtsvinding), pendapat para Pemohon Kasasi yang berpendapat bahwa Pasal 1365 BW dapat diterapkan dalam kasus ini tidak dapat dibenarkan karena penegakan lingkungan hidup dilakukan dengan standar hukum Internasional. Bahwa suatu ketentuan hukum Internasional dapat digunakan oleh hakim nasional, apabila telah dipandang sebagai "ius cogen" [sic!];21 (garis bawah dari penulis).

Dari kutipan ratio decidendi di atas, setidaknya terdapat tiga premis yang diajukan oleh Hakim Majelis Kasasi. Yakni: 1) bahwa penerapan precautionary principle bertujuan untuk mengisi kekosongan hukum; 2) penegakan lingkungan hidup dilakukan dengan 'standar' hukum internasional; dan 3) suatu norma hukum internasional dapat diterapkan oleh hakim pengadilan nasional, bila dipandang sebagai “ius cogen [sic!].” Dari premis 1) dan 3) bila dibaca bersamaan dengan pemaknaan yang biasa (plain reading), dapat dipahami bahwa precautionary principle telah dipandang sebagai jus cogens. Rasio putusan dari hakim ini menjadi menarik karena dari awal perkara dimulai, tidak ada pihak pun yang melakukan klaim atas status precautionary principle sebagai jus cogens. Sehingga, hal ini menimbulkan pertanyaan tentang penafsiran dan penalaran hukum hakim atas pelabelan status jus cogens tersebut.

Putusan tersebut diterima oleh beberapa penulis ${ }^{22}$ sebagai penemuan hukum (rechtsvinding) di bidang penegakan hukum lingkungan. Dalam kasus Mandalawangi, hakim dinilai berhasil tidak menjadi corong undang-undang dengan melakukan terobosan hukum. ${ }^{23}$ Menurut Imamulhadi, dengan menerapkan precautionary principle, hakim menerapkan apa

\footnotetext{
${ }_{19}$ Pengadilan Tinggi Bandung, Putusan Nomor 507/PDT/2003/PT.Bdg., hlm. 8.

${ }^{20}$ Mahkamah Agung, Putusan No. 1794/Pdt/2004 hlm. 84.

${ }^{21} \mathrm{Ibid}$.

${ }^{22}$ Helmi, et. al. "Documenting Land-combustion"; Imamulhadi, "Perkembangan Prinsip Strict Liability"; Hardjaloka, "Ketepatan Hakim dalam Penerapan Precautionary Principle."

${ }^{23}$ Imamulhadi, "Perkembangan Prinsip Strict Liability," hlm. 427.
} 
yang disebut sebagai teori hukum responsif. ${ }^{24}$ Dengan adanya precautionary principlepenerapan strict liability pada akhirnya dimungkinkan dan kemudian mengurangi beban pembuktian penggugat (korban), sehingga dapat hambatan pembuktian yang dialami korban berkurang. ${ }^{25}$ Atas putusan ini, Wibisana menyatakan bahwa tidak tepat bila precautionary principle dijadikan dasar pengubah aturan pertanggungjawaban (liability rule) dari pertanggungjawaban berdasarkan kesalahan menjadi strict liability. ${ }^{26}$

Meskipun muncul pelbagai pro dan kontra atas penerapan precautionary principle tersebut, putusan Mandalawangi kemudian diikuti oleh putusan-putusan setelahnya di bidang lingkungan hidup. Seperti sengketa Kementerian Lingkungan Hidup dan Kehutanan (KLHK) v. PT Kallista Alam ${ }^{27}$ dan KLHK v. PT Waringin Agro Jaya. ${ }^{28}$ Keduanya merupakan sengketa perbuatan melawan hukum atas kebakaran lahan. ${ }^{29}$ Dalam beberapa sengketa lingkungan hidup lainnya terdapat kecenderungan bagi penggugat untuk mengargumentasikan precautionary principle sekaligus statusnya sebagai jus cogens dalam posita gugatan lingkungan hidup. ${ }^{30} \mathrm{Hal}$ ini menunjukkan bahwa putusan Mandalawangi memiliki signifikansi yang besar bagi litigasi bidang lingkungan di Indonesia, meskipun status putusannya sendiri tidak menjadi yurisprudensi secara de jure. ${ }^{31}$

\section{Prinsip Kehati-hatian dan Evolusinya}

Tesadaran masyarakat internasional untuk mengakui precautionary principle yang Ldianggap dapat melindungi lingkungan secara optimal menggerakkan Hakim Mandalawangi untuk menerima prinsip tersebut. Meskipun secara gradual sudah mulai

\footnotetext{
${ }^{24}$ Penulis melihat bahwa penerapan putusan tersebut memenuhi keadilan substantif meskipun bertentangan dengan undang-undang. Lihat: Ibid., hlm. 430.

${ }^{25}$ Hardjaloka, "Ketepatan Hakim dalam Penerapan Precautionary Principle," hlm. 149.

${ }^{26}$ Wibisana, "The Development of the Precautionary Principle," hlm. 9.

${ }^{27}$ Misalnya dalam sengketa Kementerian Lingkungan Hidup dan Kehutanan (KLHK) v. PT Kallista Alam prinsip precautionary principle tersebut diaplikasikan dan diterjemahkan menjadi doktrin in dubio pro natura. Doktrin tersebut diterjemahkan menjadi "bila ada keraguan, seseorang harus mengambil tindakan yang pro terhadap lingkungan." Mahkamah Agung, Putusan No. 651/K/PDT/2015, hlm. 72-73.

28 Pengadilan Negeri Jakarta Selatan, Putusan No. 456/Pdt.G-LH/2016/PN Jkt.Sel

${ }^{29}$ Dalam KLHK v. PT Waringin Agro Jaya, konsep jus cogens dibahas singkat oleh ahli Andri Gunawan Wibisana dan Achmad Romsan dalam pemeriksaan saksi ahli. Walaupun dalam pertimbangannya hakim tidak membahas kembali status jus cogens dan serta merta menerapkan strict liability yang diterapkan dalam Mandalawangi dalam kasus tersebut.

${ }^{30}$ Misalnya Putusan Pengadilan Negeri Palangkaraya Nomor 213/Pdt.G/LH/2018/PN Plk; Putusan Pengadilan Tinggi Palembang Nomor 51/PDT/2016/PT.PLG; Putusan Pengadilan Negeri Kuala Kapuas Nomor 51/Pdt.PlwLH/2018/PN Klk; Putusan Pengadilan Negeri Banjarmasin Nomor 125/Pdt.G/LH/2016/PN Bjm; Putusan Mahkamah Agung Nomor $101 \mathrm{~K} / \mathrm{TUN} / 2013$.

31Sistem peradilan Indonesia akan merujuk putusan-putusan yang dimuat di Buku Yurisprudensi Mahkamah Agung untuk mendapat kekuatan mengikatnya.
} 
diterima, keberadaan prinsip tersebut tidak lepas dari kritik dan pertentangan. ${ }^{32}$ TrouwBorst, seorang pendukung precautionary principle, membedakan dua konsep berbeda tetapi hampir serupa, yakni antara precautionary logic dengan precautionary principle, serta preventative principle dengan precautionary principle. ${ }^{33}$ Baginya precautionary principle dirancang khusus untuk perlindungan lingkungan dan kesehatan manusia. Sementara, precautionary logic dapat ditemukan pada bidang keamanan. ${ }^{34}$ Aspek preventative dan precautionary memiliki pemahaman yang berbeda. Yakni, preventative logic adalah tindakan pencegahan di mana risiko atas bahaya atas suatu tindakan sudah diketahui dengan pasti, sementara precautionary logic adalah tindakan yang harus diambil ketika bahaya tersebut tidak diketahui. ${ }^{35}$ Sehingga, tindakan yang diambil berdasarkan precautionary principle ada sebelum preventative principle. Meskipun pada tataran praktik dan perumusan berbagai konvensi internasional yang ada, dikotomi preventative-precautionary sulit dilakukan, dan cenderung terjadi tumpang tindih atau perumusan yang digabungkan. ${ }^{36}$

Bila ditelusuri, asal muasal precautionary principle mulai muncul dari instrumen hukum lingkungan domestik dan regional di Eropa. ${ }^{37}$ Sementara di tingkat internasional tercatat bahwa Resolusi Majelis Umum PBB 1982 tentang World Charter for Nature ${ }^{38}$ sebagai soft law atau instrumen tidak mengikat. Sementara, dalam perjanjian internasional, kata "precaution" antara lain terdapat dalam 1985 Vienna Convention on Ozone Depleting Substances, 39 UNFCCC,40

\footnotetext{
${ }^{32}$ Misalnya Zander mengomentari bahwa kritik umum terhadap precautionary principle adalah bahwa prinsip tersebut tidak didefinisikan secara jelas, pendekatan yang absolutist, dan cenderung mengabaikan bukti ilmiah yang telah ada. Pendekatan yang absolutist maksudnya adalah prinsip tersebut adalah tindakan menghindari risiko (risk-aversion) secara penuh, di mana menurutnya pendekatan lain adalah melalui analisis biaya dan manfaat (cost benefit analysis). Lihat Joakim Zander, The Application of the Precautionary Principle in Practice: Comparative Dimensions, Cambridge University Press, Cambridge, 2010.

${ }^{33}$ Arie Trouwborst, 2009, "Prevention, Precaution, Logic and Law: The Relationship between the Precautionary Principle and the Preventative Principle in International Law and Associated Questions" 22 Erasmus Law Review, hlm. 105.

34 Ibid., hlm. 116.

35 Ibid., hlm. 117-119.

36 Ibid., 120.

${ }^{37}$ Misalnya European Commission menerjemahkan precautionary principle sebagai "dalam keadaan khusus di mana bukti ilmiah tidak cukup, tidak konklusif, atau tidak pasti dan terdapat indikasi melalui evaluasi pendahuluan ilmiah yang objektif terdapat dasar yang beralasan atas perhatian tentang potensi dampak bahaya terhadap lingkungan, kesehatan manusia, hewan, atau tumbuhan mungkin tidak sesuai dengan tingkat perlindungan yang dipilih." European Commission, Commission Communication on the Precautionary Principle, COM (2000) 1, hlm. 10; Emmy Latifah, 2016,"Precautionary Principle sebagai Landasan dalam Merumuskan Kebijakan Publik” 52 Yustisia, 275-297.

38 "Where potential adverse effects are not fully understood, the activities should not proceed." Lihat: Dewan Umum Perserikatan Bangsa-Bangsa, World Charter for Nature 1982, A/RES/37/7, para. 11(b).

39 "Mindful also of the precautionary measures for the protection of the ozone layer for the protection of the ozone layer which have already been taken at the national and international levels"

40 "The Parties should take precautionary measures to anticipate, prevent or minimize the causes of climate change and mitigate its adverse effects." Lihat: Perserikatan Bangsa-Bangsa, The United Nations Framework Convention on Climate Change, pasal 3.
} 
UN Convention on Biodiversity ${ }^{41}$ beserta Biosafety Protocol. ${ }^{42}$ Pada kenyataannya prinsip tersebut lebih banyak diungkapkan dalam bentuk soft law dibandingkan dengan instrumen hukum internasional yang mengikat (hard law). Precautionary principle mulai mendapat momentum setelah Rio Declaration 1992 memasukkan prinsip tersebut dalam Principle 15, yakni:

Untuk melindungi lingkungan, pendekatan kehati-hatian harus diterapkan secara luas oleh negara-negara bergantung pada kemampuan masing-masing negara. Di mana ada ancaman serius atau kerusakan yang tidak dapat dikembalikan, kekurangan kepastian ilmiah secara penuh tidak dapat dijadikan sebagai alasan untuk menunda tindakan yang efektif dari segi biaya untuk mencegah kerusakan lingkungan. ${ }^{43}$

Merujuk kembali dikotomi precautionary logic - precautionary principle dan preventative precautionary yang dikemukakan oleh Trouwborst, Prinsip 15 Deklarasi Rio dengan kata lain mengharuskan negara untuk mengambil tindakan preventif, meskipun dalam keadaan kekurangan kepastian ilmiah. Formulasi preventative logic diserap menjadi bagian precautionary principle dalam Prinsip 15.

Secara bentuk paling mendasar precautionary principle ini mensyaratkan siapapun yang menjalankan aktivitas yang berpotensi menimbulkan bahaya bagi lingkungan maupun kesehatan manusia, memiliki kewajiban untuk mencegah bahaya yang timbul dari kegiatan tersebut, 44 dimana unsur preskriptif precautionary principle yaitu adanya: 1) ancaman; 2) ketidakpastian; 3) suatu tindakan tertentu; 4) tindakan tersebut harus diambil. ${ }^{45}$ Sementara pernyataan dari Cross dalam konteks tindakan pemerintahan menggarisbawahi bahwa prinsip tersebut mengharuskan Pemerintah untuk mengambil langkah kehati-hatian untuk melindungi kesehatan publik dan lingkungan, di tengah kekosongan bukti nyata yang jelas atas bahaya yang berpotensi timbul, terlepas dari biaya yang ditimbulkan dari tindakan tersebut. ${ }^{46}$ Bagi Trouwborst yang menganggap precautionary principle sebagai hukum kebiasaan

\footnotetext{
${ }_{41}$ "Noting also that where there is a threat of significant reduction or loss of biological diversity, lack of full scientific certainty should not be used as a reason for postponing measures to avoid or minimize such a threat." Lihat: Perserikatan BangsaBangsa, The Convention on Biological Diversity, Preambule

42 Perserikatan Bangsa-bangsa, Cartagena Protocol on Biosafety, Pasal 1

${ }^{43}$ Rio Declaration 1992, Prinsip 15.

${ }^{4}$ Zander, The Application of the Precautionary Principle, hlm. 15. "According to this principle anyone who carries out an activity has the duty to prevent any harm to the environment or to human health which stems from the activity"

45 Ibid, hlm. 29.

${ }^{46}$ Cross sendiri menolak keberlakuan prinsip tersebut yang sepenuhnya merupakan tindakan penghindaran risiko. Di mana menurutnya, risiko akan selalu ada dan tidak dapat dihindari. Risiko tidak harus dihindari, tetapi harus dikurangi dengan cara-cara tertentu. Sehingga, menurutnya precautionary principle akan bersifat destruktif. Lihat: Frank B. Cross, 2016, "Paradoxical Perils of the Precautionary Principle” 533 Washington and Lee Law Review, hlm. 851.
} 
internasional terdiri dari tiga elemen utama, yakni 1) ancaman bahaya terhadap lingkungan; 2) ketidakpastian; dan 3) tindakan. ${ }^{47}$

Hingga saat ini tidak ada formulasi yang pasti tentang prinsip kehati-hatian yang telah diterima secara universal serta sulit untuk menentukan batasan dan isi dari prinsip tersebut. 48 Sehingga sulit untuk mengatakan bahwa prinsip tersebut adalah suatu prinsip hukum yang dapat diterapkan secara seragam dalam keadaan-keadaan yang serupa. ${ }^{49}$ Secara umum, terdapat dua varian formulasi normatif dari precautionary principle. Pertama, saat adanya risiko dan ketidakpastian ilmiah, suatu pihak harus mengambil tindakan. Kedua, saat adanya risiko dan ketidakpastian ilmiah, suatu pihak harus mengambil tindakan tertentu. ${ }^{50}$

Sandin dkk sebagai pendukung precautionary principle menjelaskan bahwa precautionary principle dapat digunakan dalam bentuk argumentatif maupun preskriptif. ${ }^{51}$ Precautionary principle dalam bentuk argumentatif yakni sebagai justifikasi untuk pengambilan keputusan di saat adanya ketidakpastian yang dapat berpotensi membahayakan di masa depan. Sementara, bentuk preskriptif precautionary principle dapat digunakan untuk memberikan preskripsi untuk melakukan perilaku tertentu dalam hal adanya ketidakpastian. ${ }^{52}$ Sandin dkk lebih lanjut mencontohkan, formulasi precautionary principle dalam Prinsip 15 Rio Declaration adalah bentuk lemah dari penerapan argumentatif dari precautionary principle. ${ }^{53}$ Bentuk preskriptif dapat diformulasikan menjadi bentuk normatif memiliki empat unsur yakni: jika terdapat (1) bahaya yang (2) tidak pasti, maka (3) suatu tindakan (4) harus dilakukan. ${ }^{54}$ Dari perumusan ini ini dapat dilihat bahwa terdapat sifat normatif dari precautionary principle yang melahirkan kewajiban untuk melakukan sesuatu.

Selain pada masalah perumusan definisi dan ruang lingkup prinsip tersebut yang tidak jelas, terdapat kritik terhadap precautionary principle bahwa prinsip tersebut adalah: a) absolutis; b) menghasilkan perilaku mengambil resiko (risk-taking); c) merupakan penilaian atas nilai atau 'ideologi'; d) mengesampingkan peran dari ilmu pengetahuan. ${ }^{55}$ Tentunya

\footnotetext{
${ }^{47}$ Arie Trouwborst, "The Precautionary Principle in General International Law: Combating the Babylonian Confusion" 16 RECIEL2007, hlm. 187.

${ }^{48}$ Zander, The Application of the Precautionary Principle, hlm. 31.

${ }^{49} \mathrm{Ibid} .$, hlm. 31; D. Bodansky, “Scientific uncertainty and the Precautionary Principle,” 33 Environment 1991, hlm. 5.

${ }^{50}$ Nicholas A. Ashford, 2007. "The Legacy of the Precautionary Principle in US Law: The Rise of Cost-Benefit Analysis and Risk Assessment as Undermining Factors in Health, Safety and Environmental Protection," dalam Implementing the Precautionary Principle, Nicolas de Sadeleer ed., Earthscan, London

51 Per Sandin, et. al. 2002, "Five Charges against the Precautionary Principle," 54 Journal of Risk Research, hlm. 289.

52 Ibid.; Zander, The Application of the Precautionary Principle, hlm. 28.

53 Ibid., hlm. 37.

54 Per Sandin, 1999, “Dimensions of the Precautionary Principle," 55 Human and Ecological Risk Assessment: An International Journal, hlm. 898

${ }^{55}$ Per Sandin, et. al. "Five Charges," hlm. 288.
} 
bukanlah tujuan dari tulisan ini untuk melakukan sintesis secara utuh atas dua pandangan yang berbeda tentang precautionary principle. Tetapi dari perdebatan dari segi definisional yang ada setidaknya dapat diambil benang merah bahwa, bagi para pendukung prinsip tersebut, meskipun terdapat formulasi yang tidak pasti, bentuk preskriptif lah yang dapat ditransposisi menjadi suatu norma hukum. Sementara, Prinsip ke-15 Deklarasi Rio bukanlah bentuk preskriptif.

Terlepas pertentangan pandangan dari pendukung maupun penentang precautionary principle, di dalam literatur yang eksis sebelum putusan kasasi Mandalawangi dijatuhkan, tidak ada satu pun argumen yang terlebih dahulu memberikan status jus cogens atas prinsip kehatihatian.

Sejauh ini, tidak ada putusan pengadilan maupun mahkamah internasional yang menyatakan suatu norma di bidang lingkungan eksis sebagai jus cogens. ${ }^{56}$ Sehingga, putusan Mandalawangi merupakan satu-satunya putusan di dunia yang mengakui prinsip kehati-hatian sebagai jus cogens. Cameron dan Abouchar yang mendasarkan pada teori "instant custom," yakni penerimaan norma hukum internasional yang relatif baru sebagai hukum kebiasaan internasional secara cepat. ${ }^{57}$ Dalam konteks pembahasan implementasi precautionary principle (dan bukan validitas hukumnya), Goklany mengatakan tidak bisa mengelak dari pendapat Stone bahwa precautionary principle tidak sepenuhnya tertanam di dalam kebiasaan hukum internasional dan variasi dari prinsip tersebut setidaknya dapat ditemukan di beberapa deklarasi, perjanjian, maupun konvensi hukum lingkungan internasional. ${ }^{58}$

\footnotetext{
56 Patricia Birnie, Alan Boyle dan Catherine Redgwell, 2009, International Law and the Environment, Oxford University Press, Oxford, hlm. 109-110; Krista Singleton-Cambage, 1996," International Legal Sources And Global Environmental Crises: The Inadequacy of Principles, Treaties, and Custom," 21 ILSA Journal of International \& Comparative Law, hlm. 185; Louis J. Kotzé, “Constitutional Conversations in the Anthropocene: In Search of Environmental Jus Cogens Norms," dalam Netherlands Yearbook of International Law 2015, M. Heijer, H. van der Wilt, eds.,2016 T.M.C. Asser Press, The Hague,, hlm. 252.

${ }^{57}$ Cameron dan Abouchar, "The Precautionary Principle."

J. Cameron, dan J. Abouchar, 1991, "The Precautionary Principle: A Fundamental Principle of Law and Policy for the Protection of Global Environment," 14 Boston College International and Comparative Law Review

58 Indur M. Goklany, , 2001, The Precautionary Principle : a critical appraisal of environment risk assessment, CATO Institute, Washington, D.C.
} 
Keberadaan precautionary principle sebagai bagian dari hukum internasional juga diakui dalam berbagai sengketa internasional baik di ICJ,59 ITLOS,60 maupun WTO,61 tetapi dengan resepsi yang beragam. Dari putusan-putusan tersebut dilihat bahwa hakim cenderung menghindari pembahasan tentang substansi dari precautionary principle, namun mengakui keberadaannya sebagai bagian dari hukum internasional tetapi tidak sebagai jus cogens. Terlepas dari perdebatan tentang status dari precautionary principle, suatu hal yang pasti adalah tidak ada literatur sejauh ini yang menunjukkan bahwa precautionary principle adalah jus cogens. Namun demikian, bilamana putusan tersebut dianggap sebagai terobosan hukum, apakah determinasi status tersebut dapat dibenarkan secara doktrinal sebagai jus cogens? Sesungguhnya, apa saja kualifikasi yang dapat membuat suatu norma hukum menjadi jus cogens? Kami akan mencoba menguliti konsep tersebut dalam bagian berikut di bawah.

\section{Makhluk Abstrak itu Bernama Jus Cogens}

nggapan hakim atas status jus cogens dari precautionary principle menjadi penting untuk
dikritisi karena karakter dari jus cogens merupakan norma hukum internasional yang bersifat fundamental. ${ }^{62}$ Karakter fundamental konsep ini diartikulasikan oleh Suy, yang

\footnotetext{
${ }^{59}$ Antara lain, Hakim Palmer dalam dissenting opinion-nya dalam French Nuclear Test II, ada kemungkinan bahwa precautionary principle menjadi hukum kebiasaan internasional. Akan tetapi, pernyataan tersebut baru menunjukkan adanya kemungkinan, bukan suatu penentuan status sendiri (" it 'may' be the case that precautionary principle forms part of customary international law."). Mahkamah Internasional, "Request for an Examination of the Situation in Accordance with Paragraph 63 of the Court's Judgment of 20 December 1974 in the Nuclear Tests (New Zealand v. France)"(1974), Dissenting opinion of Judge Palmer, hlm. 412; Dalam sengketa Gabcikovo-Nagymaros, Mahkamah Internasional berpendapat bahwa precautionary principle dapat norma baru dari hukum lingkungan internasional, tetapi tidak secara khusus menentukan penafsiran atas precautionary principle; Mahkamah Internasional, Gabčíkovo-Nagymaros Project (Hungary/Slovakia), (1977), para. 112.

${ }^{60}$ Dalam Southern Bluefin Tuna, Selandia Baru dan Australia meminta International Tribunal for the Law of the Sea (ITLOS) menghentikan perikanan eksperimental Jepang karena adanya precautionary principle untuk melindungi spesies tuna sirip biru. Meskipun pada akhirnya ITLOS tidak merujuk spesifik tentang precautionary principle. ITLOS, Southern Bluefin Tuna (N.Z. v. Japan) (Austl. v Japan), 381 I.L.M. 1.624 (Provisional Measures Order of Aug. 27, 1999), para. 34; Di ITLOS pula Irlandia dalam sengketa MOX Plant menggunakan argumen precautionary principle untuk membalik beban pembuktian terhadap Inggris, tetapi dalam putusannya ITLOS tidak memberikan analisis apapun terkait prinsip kehati-hatian. ITLOS, The MOX Plant Case (Ireland v. United Kingdom), Provisional Measures.

${ }^{61}$ Dalam kerangka hukum WTO, bentuk turunan dari precautionary principle itu sendiri yang telah diakui dalam Pasal 5.7 WTO Agreement on Sanitary and Phytosanitary Measures. Tetapi kata "may" dalam perumusan tersebut menunjukkan bahwa dalam WTO SPS Agreement, precautionary principle bersifat fakultatif. Sehingga, konten normatif dari precautionary principle tersebut telah menjadi perdebatan antar anggota WTO dalam sengketa, misalnya kasus EC - Biotech dan EC - Hormones, tetapi dalam kedua kasus tersebut Badan Banding WTO tidak menjawab status hukum precautionary principle. Lihat: WTO, European Communities - Biotech, para. 7.88; WTO, European Communities - Measures Concerning Meat and Meat Products (Hormones). Sri Wartini, "Implementasi Prinsip Kehati-hatian dalam Sanitary and Phytosanitary Agreement, Studi Kasus: Keputusan Appellate Body WTO dalam Kasus Hormone Beef antara Uni Eropa dengan Amerika Serikat," 142 Jurnal Hukum Ius Quia Iustum, 2007, 296 - 313; Denise Prevost, “What Role for the Precautionary Principle in WTO Law after Japan-Apples?” 24 Economic Policy and Law: Journal of Trade \& Environmental Studies, 2005, 1-14.

${ }^{62}$ Martti Koskenniemi, "Fragmentation of International Law: Difficulties Arising from the Diversification and Expansion of International Law," UNGA A/CN.4/L.682, 13 April 2006, 182.
} 
mengatakan bahwa oleh karena karakteristik fundamentalnya tersebut, pelanggaran atau ketidakpatuhan akan norma jus cogens akan berdampak pada hakikat mendasar dari sistem hukum internasional, dan segala perbuatan yang melawan jus cogens akan menjadi batal secara absolut. Shelton lebih lanjut menjelaskan bahwa karena pelanggaran jus cogens akan menimbulkan guncangan bagi 'kesadaran umat manusia' 63 ia tidak dapat dikecualikan seperti halnya aturan persistent objector dalam konteks kemunculan norma hukum kebiasaan internasional. ${ }^{64}$

Meskipun memiliki kekuatan normatif yang bersifat suprematif, jus cogens adalah satu konsep yang mistis dalam alam hukum internasional. ${ }^{65}$ Ia dipahami sebagai suatu norma yang bersifat tertinggi, yang dapat menyampingkan norma hukum internasional lainnya. ${ }^{66}$ Menurut d'Aspremont, jus cogens adalah konstruksi sosial yang sudah mencapai suatu kematangan pasca-ontologis (post-ontological maturity) dimana keberadaan konsep jus cogens tanpa ada persetujuan tentang bagaimana bisa persisnya konsep tersebut telah ada dalam sistem pemikiran hukum internasional. ${ }^{67} \mathrm{Akan}$ tetapi, pertanyaan-pertanyaan tentang jus cogens akan berkutat pada konten dari jus cogens dan dampak normatif yang ditimbulkan dari jus cogens itu. ${ }^{68}$ Sehingga oleh d'Aspremont, jus cogens dipandang sebagai konstruksi sosial tanpa silsilah (social construction without pedigree). ${ }^{69}$

Bila ditelaah dari kacamata hukum perjanjian internasional, keberadaan konsep jus cogens dalam hukum internasional dapat dilihat dari Perjanjian Wina tentang Perjanjian Internasional (Vienna Convention on the Law of Treaties70, VCLT 1969), yakni dalam Pasal 53 dan Pasal 64. Dalam Pasal 53 VCLT dinyatakan bahwa, suatu perjanjian internasional akan batal bila dalam penyelesaiannya berbenturan dengan norma hukum internasional umum (peremptory norm of general international). ${ }^{71}$ Sementara menurut Pasal 64 VCLT, bila suatu norma

$63^{\text {" }}[. .$.$] the body of those general rules of law whose non-observance may affect the very essence of the legal system$ to which they belong to such an extent that the subject of law may not, under pain of absolute nullity, depart from them in virtue of particular agreements." Lihat: Suy dalam Ian Sinclair, 1984, The Vienna Convention on the Law of Treaties, 2nd ed., Manchester: Manchester University Press, hlm. 110.

${ }^{64}$ Dinah Shelton, 2006, "Normative Hierarchy in International Law," 1002 American Journal of International Law, hlm. 313

${ }^{65}$ J. d'Aspremont, 2002, "Jus Cogens as a Social Construct Without Pedigree," dalam M. Heijer M. dan H. N. van der Wilt, eds. Netherlands Yearbook of International Law 2015, vol. 46. The Hague: T.M.C. Asser Press, 2016, hlm 89.

${ }_{66}$ International Criminal Tribunal for the former Yugoslavia, Prosecutor v. Anto Furundžija, Judgment of 10 December 1998, Case No. IT-95-17/1, Trial Chamber II; Lihat juga: ILR vol. 121, hlm. 260, para. 153.

${ }^{67} \mathrm{~d}$ 'Aspremont, “Jus Cogens," hlm. 89.

68 Ibid., hlm. 87.

${ }^{69} \mathrm{Ibid} ., \mathrm{hlm} .89$.

${ }^{70}$ Perserikatan Bangsa-Bangsa, Vienna Convention on the Law of Treaties, 23 May 1969 dalam UN Treaty Series vol. 1155, hlm. 331

71 Ibid., pasal 53. 
hukum yang tidak terelakkan yang baru muncul dan bertentangan dengan perjanjian yang telah ada, perjanjian yang telah ada menjadi serta merta batal demi hukum dan berakhir. ${ }^{72}$ Pasal ini menyiratkan jus cogens dapat berada sebagai norma yang berasal dari eksternal suatu perjanjian internasional maupun sebaliknya jus cogens dapat muncul dari norma dalam perjanjian internasional sepanjang norma tersebut sudah dianggap fundamental oleh masyarakat internasional.

Secara garis besar, dalam perdebatan kontemporer terdapat dua aliran pemikiran utama yang mendasari adanya jus cogens, yakni argumen hukum kodrat (natural law) serta argumen positivis. Argumen hukum kodrat menjelaskan bahwa asal norma jus cogens bersumber norma yang bersifat transenden untuk melindungi moral dan nilai mendasar dari umat manusia dalam masyarakat internasional. Hal ini tercermin dalam putusan Inter-American Commission on Human Rights bahwa norma jus cogens "haruslah bersumber dari tatanan norma yang lebih tinggi, yang ada dari zaman kuno, dan tidak dapat dilawan oleh hukum manusia maupun bangsa-bangsa." Serta, norma tersebut "diterima karena perlu untuk melindungi kepentingan publik dari masyarakat bangsa-bangsa atau menjaga tingkatan moralitas publik yang diakui oleh masyarakat bangsa-bangsa tersebut."73

Sejak adanya pembahasan VCLT, diskursus tentang jus cogens mulai banyak diwarnai oleh pandangan hukum kodrat. ${ }^{74}$ Salah satunya datang dari Dupuy yang secara tegas menolak keberadaan jus cogens sebagai bagian dari hukum kodrat. ${ }^{75}$ Ciri utama dari argumen positivis adalah bahwa hukum akan tidak bergantung dari moralitas, serta berasal dari sumber lain dengan proses pembuatan keputusan yang otoritatif atau berasal dari suatu grundnorm yang dianggap ada. ${ }^{76}$ Dalam kacamata positivis, jus cogens adalah hasil dari kesepakatan dari negaranegara baik berupa kesepakatan eksplisit maupun implisit. Menurut Judge Schücking dalam Separate Opinion putusan Oscar Chinn, kualifikasi suatu norma sebagai jus cogens harus

\footnotetext{
72 "If a new peremptory norm of general international law emerges, any existing treaty which is in conflict with that norm becomes void and terminates."

$73^{\prime \prime}$ derived from a higher order of norms established in ancient times and which cannot be contravened by laws of man or nations." "accepted [...] as necessary to protect the public interest of the society of nations or to maintain levels of public morality recognised by them." Inter-American Commission on Human Rights, Victims of the Tugboat "13 de Marzo" v. Cuba, Case 11.436, Inter-Am. C.H.R., Report No. 47/96, OEA/Ser.L/V/II.95, doc. 7 rev. 1791996.

${ }^{74}$ Formulasi Pasal 53 jus cogens menurut Orakhelashvili secara serta merta mengabaikan teori Verdross-Lauterpacht yang menegaskan bahwa jus cogens tidak berdasarkan kesepakatan konsensual. Lihat Orakhelashvili, hlm. 106.

${ }_{75}$ "N'étant pas du droit naturel, le jus cogens a une histoire; il constitue un produit, non un donné normatif." Pierre-Marie Dupuy, "Le jus cogens, les mots et les choses. Où en est le droit impératif devant la CIJ près d'un demi-siècle après sa proclamation?," dalam Enzo Cannizzaro, The Present and Future of Jus Cogens, 2015, Sapienza Università Editrice, Roma, hlm. 99.

${ }^{76}$ Uri Linderfalk, 2016, “Understanding the Jus Cogens Debate: The Pervasive Influence of Legal Positivism and Legal Idealism," dalam Netherlands Yearbook of International Law 2015 Jus Cogens: Quo Vadis?, Maarten den Heijer dan Harmen van der Wilt, eds., TMC Asser Press, Den Haag, hlm. 55.
} 
disepakati oleh negara, disepakati untuk tidak boleh diubah oleh sebagian negara, dan tindakan yang melawan norma tersebut secara serta merta akan batal demi hukum. ${ }^{77}$

Orakhelashvili menjelaskan ada dua teori yang menjelaskan asal keberlakuan jus cogens. Pertama, teori konstitusional, di mana norma jus cogens beroperasi dianalogikan sebagai konstitusi dalam ruang hukum domestik. Sementara teori yang lainnya adalah teori ketertiban umum (ordre public), yakni adanya jus cogens beroperasi menggunakan logika hukum keperdataan domestik di mana ada norma yang superlatif yang membatasi kebebasan kontraktual bagi para pihak. ${ }^{78}$ Pemikiran ini didasarkan oleh argumen yang diajukan oleh Verdross. ${ }^{79}$ Menurutnya, pembatasan pembentukan perjanjian internasional mirip dengan konsep ketertiban umum atau ordre public dalam konsep hukum perdata internasional, yakni membatasi kemampuan kebebasan para pihak (negara) untuk membuat negara sesuai dengan kehendaknya masing-masing. ${ }^{80}$

Berbeda dengan hukum kebiasaan internasional, bagi Verdross, unsur terpenting dari norma jus cogens ada karena sifatnya yang fundamental dalam tatanan hukum internasional, yakni menjadi norma yang tidak boleh dilanggar karena bersifat bonos mores yakni mencerminkan nilai moral yang baik. Nilai-nilai tersebut haruslah tercermin secara umum dari sistem hukum yang ada di seluruh dunia. ${ }^{81}$ Sehingga, dalam karya seminalnya tersebut, Verdross menyimpulkan bahwa suatu perjanjian internasional tidak bisa bersifat contra bonos mores. ${ }^{82}$ Jus cogens dianggap sebagai sebagai moralitas positif yang mendasar, adanya pranata jus cogens memberikan dasar moral bersama (shared moral foundations) dari masyarakat internasional. 83 Sehingga, jus cogens mencerminkan kebaikan bersama masyarakat internasional yang bersifat transenden. ${ }^{84}$ Norma tersebut harus diterima oleh masyarakat internasional secara keseluruhan, meskipun kenyataan bahwa dalam berbagai sistem hukum di dunia dibangun atas konsepsi moral yang berbeda. ${ }^{85}$

\footnotetext{
${ }_{77}$ The Oscar Chinn Case, PCIJ, Judgment of 12 December 1934, Separate opinion of Judge Schücking, hlm. 149-150

${ }^{78}$ Orakhelashvili, Peremptory Norms, hlm. 9.

${ }^{79}$ Albert Verdross, "Jus Dispositivum and Jus Cogens in International Law," 55 American Journal of International Law, 1966.

${ }^{80}$ Alfred Verdross, “Forbidden Treaties in International Law: Comments on Professor Garner's Report on the 'Law of Treaties'” 314 American Journal of International Law 1937, hlm. 572.

${ }^{81}$ Dalam tulisannya Verdross masih menerapkan paham dikotomi civilized-non-civilized nations. Sementara dalam pembahasan kontemporer, dikotomi tersebut irelevan.

82Sehingga, bisa dikatakan bahwa jus cogens berasal dari prinsip-prinsip hukum yang umum, yang tercermin dari sistem hukum nasional. Lihat: Verdross, "Forbidden Treaties," hlm. 577.

${ }^{83}$ d'Aspremont, hm. 92; Hersch Lauterpacht, 2015, First Report on the Law of Treaties [1953] II YbILC 154-6, para. 4; Thomas Weatherall, Jus Cogens: International Law and Social Contract, Cambridge: CUP, hlm. 67.

${ }^{84}$ Brundner, 1988, The Domestic Enforcement of International Covenant on Human Rights," 35 University Toronto Law Journal 35 hlm. 249-250; Orakhelashvili, Peremptory Norms, hlm. 47.

85 Verdross, "Forbidden Treaties."
} 
Sementara, mengenai kontur normatif dari jus cogens, tidak ada sumber otoritatif tunggal yang memberikan daftar presisi tentang jus cogens. ${ }^{86}$ International Law Commission (ILC) melalui Special Rapporteur Dire Tladi pada tahun 2015 mulai bekerja untuk melakukan upaya penelusuran Kembali atas pemaknaan jus cogens. ${ }^{87}$ ILC memberikan penjelasan bahwa tidak ada kriteria sederhana untuk menentukan aturan hukum internasional umum sebagai norma yang memiliki karakter jus cogens. ${ }^{88}$ Jus cogens saat ini telah eksis sebagai praktik yudisial yang empirik. ${ }^{89}$ Sehingga, salah satu keberadaan jus cogens dapat diketahui dari putusan-putusan pengadilan internasional maupun domestik. ILC memberikan daftar non-exhaustive beberapa norma yang sudah mendapatkan status jus cogens, antara lain adalah: a) larangan agresi; b) larangan genosida; c) larangan perbudakan; d) larangan apartheid dan diskriminasi ras; e) larangan atas kejahatan terhadap kemanusiaan; f) larangan penyiksaan; g) hak untuk menentukan nasib sendiri; h) aturan-aturan dasar hukum humaniter internasional. 90 Sebelumnya ILC, de Wet juga telah mengidentifikasi beberapa norma hukum internasional yang mendapatkan status jus cogens. ${ }^{91}$ Dari daftar di atas, dapat ditarik garis lurus bahwa norma jus cogens adalah norma yang bersifat bersifat memaksa, sehingga isi norma tersebut lazimnya berupa larangan (verbot atau prohibition) maupun kewajiban (mogen atau obligation), sehingga norma tersebut akan mendalilkan perilaku yang secara positif maupun negatif. ${ }^{92} \mathrm{Jus}$ cogens harus ditaati oleh negara, sehingga lazimnya norma tersebut tidak berisi tentang kebolehan atau norma fakultatif, memberikan keleluasaan maupun margin otonomi bagi negara melaksanakan norma tersebut atau tidak.

Dalam formulasi VCLT, diketahui bahwa jus cogens yang baru dapat muncul seiring dengan waktu sehingga, norma hukum internasional yang semula tidak mendapat status jus cogens dapat berubah menjadi jus cogens melalui teknik tertentu. Luhulima ${ }^{93}$ yang merujuk

\footnotetext{
${ }^{86}$ Koskenniemi, "Fragmentation of international law"

${ }^{87}$ Catatan pribadi dari Special Rapporteur Dire Tladi dalam ILC. Lihat: Dire Tladi, “Codification, Progressive Development, New Law, Doctrine, and the Work of the International Law Commission on Peremptory Norms of General International Law (Jus Cogens): Personal Reflections of the Special Rapporteur," 13 FIU Law Review 2019, hlm. 1137-1150.

${ }^{88}$ Draft Articles on the Law of Treaties, Report of the International Law Commission on the work of its eighteenth session, 1966

${ }^{89}$ d'Aspremont, “Jus cogens," hlm. 87.

${ }^{90}$ Dewan Umum Perserikatan Bangsa-Bangsa, Fourth report on peremptory norms of general international law (jus cogens) by Dire Tladi, Special Rapporteur, A/CN.4/727.

${ }^{91}$ Kotzé, "Constitutional Conversations," hlm. 243; De Wet, 2012, hlm. 543. Menurut de Wet beberapa jus cogens adalah a) larangan penggunaan ancaman atau kekerasan terhadap kesatuan teritorial atau kemerdekaan politis negara manapun; b) larangan genosida; c) larangan penyiksaan; d) kejahatan terhadap kemanusiaan; e) larangan perbudakan dan apartheid; f) dan larangan penggunaan kekerasan terhadap warga sipil.

${ }_{92}$ Alfred Verdross, "Forbidden Treaties," hlm. 571.

${ }^{93}$ Hendro Valence Luhulima, "Identifikasi dan Validitas Norma-norma Jus Cogens dalam Hukum Internasional," 311 Justitia et Pax 2018, 69-98.
} 
literatur literatur positivis menjelaskan bahwa, bila melihat dari formulasi Pasal 53 VCLT, yakni dari perspektif perjanjian internasional, untuk menentukan apakah suatu norma dalam perjanjian internasional termasuk jus cogens atau bukan, norma tersebut harus memenuhi tiga syarat. Pertama, harus adanya double consent (persetujuan ganda) yang mengakui dan menyetujui norma tersebut dan memperlakukannya sebagai jus cogens. Kedua, universalitas dari norma tersebut yang diterima oleh masyarakat internasional secara keseluruhan. Serta ketiga, substansi norma tersebut haruslah norma yang fundamental. Kriteria-kriteria tersebut lebih tepat dalam menjelaskan kriteria transformasi norma perjanjian internasional menjadi jus cogens. ${ }^{94}$ Karena kriteria ini menitikberatkan pada persetujuan negara, sementara dengan adanya karakteristik fundamental dan bobot norma yang melekat pada norma jus cogens itu, keberlakuan jus cogens akan terlepas dari kehendak negara sebagaimana telah diuraikan di atas. 95

Sementara, dalam laporan ILC terbaru atas studi tentang jus cogens, ILC menjelaskan bahwa kualifikasi mendasar yang menjadi tolok ukur apakah suatu norma menjadi jus cogens atau tidak berpedoman pada beberapa unsur-unsur berikut. Pertama, norma tersebut tidak boleh ada pengecualiannya atau dikesampingkan. Kedua, norma tersebut haruslah norma hukum internasional yang umum. Ketiga, norma jus cogens tersebut diterima dan diakui oleh masyarakat internasional secara utuh. Keempat, norma tersebut berlaku universal. Kelima, norma tersebut bersifat superior daripada hukum internasional. Serta, keenam, norma jus cogens bertujuan untuk melindungi nilai fundamental dari masyarakat internasional. ${ }^{96}$

Argumen-argumen dalam perdebatan teoritis yang telah kami uraikan menunjukkan bahwa, mengutip kembali d'Aspremont, jus cogens eksis dalam ranah hukum internasional karena adanya ketidaksepakatan di antara para sarjana hukum internasional yang terus menerus. Sehingga, dalam meletakkan label jus cogens terhadap suatu norma hukum internasional merupakan upaya yang kontroversial, mengingat karakter dari jus cogens itu sendiri. Kami dalam tulisan ini tidak dalam posisi untuk berpihak terhadap satu teori tentang asal mula dan sumber dari jus cogens, tetapi pada pemberian gambaran singkat tentang sifat jus cogens yang fundamental beserta unsur-unsur pembentuknya. Dalam bagian berikutnya, kami akan mendekonstruksi pemikiran Hakim-hakim dalam menjustifikasi pelabelan precautionary principle sebagai jus cogens dalam putusan Mandalawangi.

\footnotetext{
${ }^{94}$ Ibid., hlm. 87-88.

${ }^{95}$ Lihat: Orakhelashvili, Peremptory Norms, hlm. 38.

${ }^{96}$ First report of the Special Rapporteur on Jus Cogens, ILC Report, A/71/10, 2016.
} 


\section{Mandalawangi: Suatu Kesalahpahaman yang Menjadi Terobosan Hukum}

$\mathrm{P}$ utusan Hakim dalam Mandalawangi yang menerima precautionary principle sebagai jus cogens amatlah kurang tepat. Hal ini karena dua posisi utama: Pertama, precautionary principle nyatanya adalah prinsip, tidak dikualifikasi sebagai norma hukum internasional. Prinsip hukum adalah suatu asas yang bekerja di balik suatu norma hukum yang kemudian diturunkan menjadi norma konkret baik berupa larangan, keharusan, maupun kebolehan. Memang, perdebatan teoritis menunjukkan bahwa precautionary principle dapat diterjemahkan dan diturunkan dalam bentuk normatif, yakni larangan untuk melakukan sesuatu di tengah ketidakpastian ilmiah dan adanya risiko yang besar atas kerusakan lingkungan, maupun bentuk normatif keharusan untuk melakukan sesuatu meskipun adanya ketidakpastian ilmiah dan risiko kerusakan lingkungan yang besar. Namun, standar norma yang digunakan Hakim dalam Mandalawangi untuk menentukan kandungan normatif dari precautionary principle tersebut tidak jelas. Sebagaimana diungkapkan oleh Sandin, Prinsip 15 Rio Declaration tidak berisi suatu preskripsi normatif, namun merupakan bentuk argumentatif.

Kedua, bila pun kandungan normatif yang terdapat prinsip telah diketahui, tidak serta merta menjadikan prinsip tersebut menjadi jus cogens karena adanya perhatian dari masyarakat internasional atas lingkungan. Kami telah membahas dalam bagian-bagian sebelumnya bahwa karakter suatu norma yang diartikulasikan sebagai jus cogens adalah norma yang lekat dengan erat nilai fundamental dan moralitas dari masyarakat internasional secara kolektif. Terlepas dari pandangan positivis maupun kodrati, ILC mengambil jalan tengah bahwa untuk menunjukkan suatu norma hukum internasional tersebut jus cogens atau bukan, norma tersebut haruslah: ${ }^{97} 1$ ) tidak ada pengecualiannya; 2) norma hukum internasional yang umum; 3) harus diterima dan diakui oleh masyarakat internasional secara umum; 4) norma tersebut berlaku secara universal; 5) norma tersebut bersifat superior; 6) bertujuan untuk melindungi nilai fundamental dari masyarakat internasional. Mengacu kepada kriteria ILC tersebut, sulit rasanya precautionary principle - sekalipun sudah berevolusi menjadi norma yang solid, dianggap sebagai jus cogens.

Operasionalisasi ini cenderung berbeda dengan bentuk jus cogens lain yang sudah lebih lazim diterima, misalnya adalah larangan atas perbudakan. Larangan atas perbudakan merupakan larangan dalam bentuk absolut, tidak ada pengecualian apapun yang menjustifikasi perbuatan tersebut, tidak ada prakondisi apapun yang mengecualikan penerapan larangan tersebut. Kemudian, sejauh ini, prinsip tersebut hanya diakui sebagai

\footnotetext{
${ }^{97}$ ILC, First Report on jus cogens, para. 59.
} 
dalam bagian khusus dari hukum internasional yakni hukum lingkungan internasional, bukan menjadi hukum internasional yang umum. Perdebatan tentang konten dan status normatif dari precautionary principle dalam selalu ada. Sehingga konten normatif dari prinsip tersebut belum diterima secara koheren, hal ini terlihat jelas dari praktik dan pandangan yang berbeda antara Amerika Serikat dan Uni Eropa terkait pemahaman atas precautionary principle. ${ }^{98}$ Konsekuensinya, universalitas norma tersebut pun menjadi pertanyaan. Kemudian, apakah kepentingan atas lingkungan merupakan nilai fundamental dari masyarakat merupakan perdebatan yang masih terbuka hingga kini. Hal ini berbeda dengan jus cogens yang lain yang sudah diakui secara lebih stabil, misalnya larangan genosida. Namun demikian, precautionary principle tidak sepenuhnya gagal dalam memenuhi kriteria jus cogens menurut ILC, bila ia diterima sebagai kebiasaan internasional, precautionary principle dapat menjadi norma hukum internasional yang bersifat superior. Karena cara kerja prinsip tersebut yakni untuk menyampingkan norma hukum internasional lain dalam hal kekurangan atau ketidakpastian bukti ilmiah untuk mencegah kerusakan lingkungan.

Namun demikian, tidak menutup kemungkinan bahwa di masa depan terdapat jus cogens lahir dari norma hukum lingkungan internasional, meskipun Orakhelashvili mengatakan bahwa jarang adanya bukti tentang karakter jus cogens melekat atas norma-norma tertentu dalam hukum lingkungan internasional. ${ }^{99}$ Dari literatur, jus cogens atas norma hukum lingkungan internasional telah dieksplorasi oleh Hannikainen dan Kotze dengan argumentasi yang berbeda. ${ }^{100}$ Dari praktik Mahkamah Internasional, Dupuy pun menjelaskan bahwa dalam Gabčíkovo-Nagymaros, Mahkamah Internasional tidak menolak sama sekali keberadaan jus cogens yang dapat yang muncul dari norma hukum lingkungan internasional. ${ }^{101}$ Namun demikian, sejauh ini tidak ada bukti yang mendasari argumentasi bahwa precautionary principle sebagai norma jus cogens kecuali putusan Mandalawangi itu sendiri. Oleh karena itu, putusan Mandalawangi akan menjadi menjadi argumen sirkuler karena nyatanya Hakim telah melakukan penilaian sendiri atas status normatif precautionary principle sebagai jus cogens, dan hal tersebut diterima post factum dalam konteks hukum nasional Indonesia tanpa adanya kritik atas penalaran hukum seperti itu. Sementara secara doktrinal, jus cogens haruslah

\footnotetext{
${ }^{98}$ Berdasarkan pengamatan berbagai penulis, namun Sunstein sendiri menolak dikotomi perbedaan pandangan Amerika Serikat - Eropa tersebut. Lihat: Sunstein, Laws of Fear, hlm. 13.

${ }_{99}$ Orakhelashvili, Peremptory Norms, hlm. 65.

${ }^{100}$ Lihat: Lauri Antero Hannikainen, 1988, Peremptory Norm (Jus Cogens) in International Law - Historical Development, Criteria, Present Status, Helsinki: Finnish Lawyers' Publishing Co., Helsinki, hlm. 688-695; Kotzé, “Constitutional Conversations," hlm. 266.

101P-M Dupuy, L'Unité de l'ordre juridique international: cours général de droit international public, Martinus Nijhoff, 200, hlm. 292.
} 
mencerminkan nilai fundamental dan diterima oleh masyarakat internasional secara utuh, tidak hanya cerminan nilai fundamental masyarakat Indonesia. Kami memahami bahwa tujuan hakim dalam menerapkan konsep jus cogens bagi precautionary principle adalah untuk menerapkan hukum yang progresif. Karena prinsip kehati-hatian belum menjadi norma hukum positif di Indonesia. Pandangan serupa juga telah dinyatakan oleh beberapa penulis. ${ }^{102}$ Namun demikian, sayangnya, dalam melakukan konstruksi hukum progresif tersebut dapat dikatakan nir-landasan dan lemah secara doktrin. Secara metodologi, misalnya bila merujuk praktik Inter-American Court of Human Rights, untuk mencapai kesimpulan bahwa prinsip nondiskriminasi adalah jus cogens dalam bentuk 'larangan melakukan diskriminasi', Hakim IACHR memeriksa belasan konvensi dan instrumen terkait HAM baru mencapai kesimpulan yang ada. ${ }^{103}$ Sangat disayangkan metodologi yang solid tidak muncul dalam ratio decidendi putusan Mandalawangi. Sejatinya, tanpa adanya label jus cogens atas suatu konsep hukum internasional pun hakim dapat menerapkan konsep hukum internasional sebagai hukum nasional karena adanya kekosongan hukum. Praktik demikian telah terjadi di ranah hukum kekayaan intelektual.104

Resepsi serta merta atas putusan Mandalawangi oleh para kalangan akademik pun menimbulkan suatu permasalahan. Imamulhadi menyatakan bahwa hakim telah melakukan konversi Rio Declaration yang merupakan soft law menjadi hard law yang memiliki daya ikat. ${ }^{105}$ Dikotomi suatu instrumen hukum internasional menjadi soft law atau hard law bergantung pada karakteristik daya ikatnya. Yakni apakah instrumen tersebut memberikan dampak normatif bahwa instrumen tersebut menghasilkan kewajiban untuk dipatuhi atau tidak. Hakim dalam Mandalawangi tidak melakukan konversi Rio Declaration menjadi hard law. Rio Declaration tetaplah instrumen soft law karena substansi instrumen tersebut tidak menimbulkan kewajiban negara apapun untuk mematuhi deklarasi tersebut. Tetapi, apa yang dilakukan

\footnotetext{
${ }^{102}$ Hardjaloka, "Ketepatan Hakim dalam Penerapan Precautionary Principle,” Imamulhadi, “Perkembangan Prinsip Strict Liability"

103Inter-American Court of Human Rights, Juridical Condition and Rights of the Undocumented Migrants, para. 100 (quoting Juridical Condition and Rights of the Child, Advisory Opinion, (ser. A) No. 17, para. 45 (2002)).

104Saat Indonesia telah meratifikasi TRIPs (Agreement on Trade-Related Aspects of Intellectual Property Rights (Annex 1C to the Agreement establishing the World Trade Organization of April 15, 1994) namun belum ada ketentuan yang jelas mengenai penerapan merek terkenal (well-known marks) hakim akan merujuk ketentuan TRIPs secara langsung. Misalnya PN Jakarta Pusat, Putusan No. 06/Merek/2001/PN.Niaga/JKT.PST Audemars Piguet Holding, S.A. v. PT. Adi Perkasa dkk; Putusan Mahkamah Agung No. 04/K/N/HaKI/2005 Hawley \& Hazel (BVI) Co. Ltd. dkk v. Boediono Tjiptodihardjo; Putusan PN Niaga Jakarta Pusat No.14/Merek/2004/PN.Niaga.Jkt.Pst Watsons Enterprises Ltd. v. PT Senshido Beautyana Semesta dkk; Putusan PN Niaga Jakarta Pusat, Putusan No. 77/Merek/2003/PN.Niaga.Jkt.Pst. Hakim-hakim lazim menerapkan Pasal 16(3) TRIPs yang merujuk Pasal 5bis Konvensi Paris tentang perlindungan merek terkenal. Pasal tersebut diberlakukan dalam pertimbangan hakim karena absennya kekosongan hukum peraturan pelaksana yang menentukan merek terkenal.

105Imamulhadi, "Perkembangan Prinsip Strict Liability," hlm. 430.
} 
hakim merupakan bentuk konkret pengakuan atau penundukan Indonesia atas precautionary principle yang diformulasikan menurut Prinsip 15 Rio Declaration. Rio Declaration tetaplah soft law karena daya ikatnya (bindingness) tidak berubah. Terlepas perdebatan apakah Prinsip 15 sudah menjadi hukum kebiasaan internasional atau belum, putusan hakim Mandalawangi signifikan bagi doktrin hukum internasional sebagai salah satu sampel untuk mengetes aspek praktik negara dan opinio juris. Kemudian Imamulhadi juga menegaskan bahwa hakim tidak boleh hanya terikat pada Undang-undang, tetapi juga harus melihat sumber hukum lain, yakni kebiasaan, konvensi, traktat, yurisprudensi, dan doktrin. ${ }^{106}$ Dalam putusan Mandalawangi, kami melihat justru hakim abai atas yurisprudensi dan doktrin yang ada, karena sebagaimana telah kami bahas sebelumnya, tidak ada bukti empirik baik sebelum atau sesudah putusan Mandalawangi, baik berupa doktrin maupun yurisprudensi internasional yang menyatakan bahwa precautionary principle telah mendapatkan status jus cogens.

Selain itu terdapat observasi dari Hardjaloka, yakni menurutnya jus cogens bisa dikategorikan sebagai suatu hukum kebiasaan internasional. ${ }^{107} \mathrm{Di}$ sini pernyataan tersebut tidak sepenuhnya salah, sebaliknya tetapi semestinya jus cogens tidak dapat direduksi menjadi hukum kebiasaan internasional semata, karena jus cogens sejatinya berbeda dengan jus dispositivum. Hukum kebiasaan internasional dapat berupa jus cogens maupun jus dispositivum tergantung seberapa fundamental dan universal norma tersebut, dan apakah pelanggaran atas norma tersebut menimbulkan suatu 'keguncangan' bagi masyarakat internasional, serta bersifat tidak dapat dikecualikan. Kemudian, Hardjaloka sepakat dengan penerapan 'ius cogens' oleh Hakim, ${ }^{108}$ tetapi sayangnya tanpa melengkapi pertanyaan yang disisakan oleh Majelis Hakim kasasi.

Pelabelan jus cogens atas suatu norma hukum merupakan tugas berat bagi Hakim, mengingat karakter jus cogens yang fundamental, perlu penjabaran dan justifikasi lebih lanjut mengapa suatu norma dapat dikatakan sebagai jus cogens dalam putusannya. Tentunya, terdapat ramifikasi dari pelabelan suatu norma menjadi jus cogens dalam putusan hukum domestik. Pertama, semua norma yang bersifat jus cogens akan dapat serta merta digunakan sebagai dasar hukum dalam pengadilan nasional, meskipun belum adanya ratifikasi Indonesia maupun terikatnya Indonesia dalam norma hukum internasional tersebut. Hal ini karena dalam putusan Mandalawangi secara harfiah Majelis Hakim kasasi menyatakan, "[Suatu hukum internasional dapat digunakan oleh hakim nasional apabila telah dipandang sebagai 'ius

\footnotetext{
106 Ibid.

107Hardjaloka, “Ketepatan Hakim dalam Penerapan Precautionary Principle,” hlm. 141. 108 Ibid.
} 
cogen'[sic!]" Sehingga, argumen jus cogens dalam Mandalawangi adalah salah satu teknik justifikasi untuk melakukan inkorporasi dan memberlakukan hukum internasional secara langsung (direct effect). Di satu sisi praktik ini akan memperjelas pandangan hakim atas teori hubungan hukum nasional dan hukum internasional. Yakni, Indonesia merupakan negara monis dalam konteks teori hubungan hukum internasional-nasional, setidaknya menurut hakim dalam Mandalawangi.

Kedua, jus cogens umumnya bersifat berkaitan dengan nilai fundamental dari masyarakat internasional. Oleh karenanya, beberapa norma yang melindungi hak-hak fundamental seperti HAM, larangan perbudakan maupun penyiksaan relatif tidak mendapatkan pertentangan dan sudah diterima sebagai jus cogens. Bila ditransformasikan dalam hukum nasional, norma-norma tersebut adalah norma hukum pidana substantif. Bilamana di masa depan terdapat jus cogens yang baru, apakah dengan serta merta jus cogens tersebut berlaku dalam hukum nasional dengan merujuk Mandalawangi? Kemudian, apakah penerapan langsung tersebut tidak bertentangan dengan asas nullum delictum? Atau, bagaimana bilamana di masa depan ada bagian dari masyarakat Indonesia menuntut hak penentuan nasib sendiri, karena hak tersebut statusnya adalah jus cogens sebagaimana telah dijelaskan pada bagian tersebut, apakah tuntutan tersebut harus diterima oleh hakim nasional? Atau, sebaliknya ramifikasi juga bisa dilihat dimensi akibat hukum secara eksternal. Bila diterima sebagai jus cogens, apakah pelanggaran atau precautionary principle (atau lebih tepatnya precautionary norm), akan menimbulkan obligatio erga omnes bagi negara lain untuk memaksa negara lain menerapkan norma tersebut? Tentunya elaborasi atas pertanyaanpertanyaan hipotesis di atas berada di luar lingkup tulisan ini karena keterbatasan ruang yang ada. Akan tetapi dampak normatif jus cogens yang diputus menurut Mandalawangi mungkin akan menjadi dasar pertanyaan bagi penelitian-penelitian lain.

\section{PENUTUP}

\section{Kesimpulan}

us cogens merupakan norma fundamental hukum internasional yang dikonstruksikan untuk $\int$ melindungi nilai mendasar masyarakat internasional. Dengan demikian untuk mendapatkan status jus cogens, suatu norma haruslah dapat dipandang sebagai norma yang fundamental-universal. Pelanggaran dari norma jus cogens dapat menyebabkan 'keguncangan bagi kesadaran umat manusia'. Lazimnya jus cogens berkaitan dengan hak-hak fundamental seseorang yang bersifat memaksa, yang berisi kaidah keharusan atau larangan yang tidak ada 
pengecualiannya. Dengan adanya status jus cogens lazimnya dari suatu jus cogens itu dapat melahirkan kewajiban bagi seluruh negara untuk menaati norma tersebut (obligatio erga omnes).

Sulit untuk menyatakan bahwa precautionary principle adalah jus cogens sebagaimana yang diputuskan dalam Mandalawangi dengan serta merta. Pertama, precautionary principle bukanlah jus cogens karena ia merupakan prinsip, bukan norma. Meskipun sudah lazim diterima tentang konsepnya, namun demikian, isi pasti dan aspek normatif yang presisi dari dari prinsipnya pun masih diperdebatkan saat ini. Sementara jus cogens dipahami sebagai peremptory norms of general international law, bukan peremptory principles. Memang konsep precautionary principles sudah diterima oleh masyarakat internasional, namun masih terbatas pada bidang hukum lingkungan internasional. Tidak seperti yang disyaratkan konsep oleh jus cogens yang seharusnya merupakan "norma" hukum internasional yang umum.

Meskipun tidak dikualifikasi sebagai yurisprudensi yang mengikat secara hukum, Mandalawangi memberi dampak penting bagi litigasi di bidang lingkungan hidup. Selain itu, Mandalawangi dipandang juga sebagai penerapan penemuan hukum yang memberikan keadilan substantif. Dari segi kontribusi doktrinal, dalam putusan tersebut hakim telah melakukan teknik inkorporasi hukum internasional dalam tatanan sistem hukum nasional. Di antara pembelajaran yang dapat diambil, putusan tersebut patut dikritisi karena tidak ada satupun argumen dari para pihak dalam sengketa mulai tingkat pertama hingga kasasi yang menyebutkan jus cogens. Hingga akhirnya Majelis Hakim kasasi sendiri yang melakukan penentuan status atas jus cogens, dengan hampir tidak ada alasan maupun landasan metodologis yang tepat. Hakim juga abai akan ekses dan ramifikasi yang akan timbul di masa depan terkait dengan penggunaan jus cogens sebagai justifikasi penerapan hukum internasional secara langsung dalam ranah hukum domestik. Salah satu penjelasan paling mungkin adalah bahwa hakim tertukar antara konsep hukum kebiasaan internasional dengan konsep jus cogens dalam Mandalawangi.

Perlu ditegaskan kembali, kami tidak mencoba menegasikan tentang urgensi dan perlunya precautionary principle terutama dalam konteks perlindungan terhadap lingkungan, tumbuhan, hewan, maupun manusia. Namun, kami tidak sepakat atas penentuan status jus cogens tersebut karena kesalahpahaman konsep dan doktrin hukum internasional. Oleh karena itu kedepannya kami berharap, dalam menerapkan konsep hukum internasional, justru hakim sendirilah yang harus menerapkan kehati-hatian dalam melakukan penalaran dan penerapan hukum. 


\section{Ucapan Terima Kasih}

Tami mengucapkan terima kasih kepada Profesor M. R. Andri Gunawan Wibisana atas - masukan substantif yang berharga serta Indraini Hapsari atas masukan dari aspek penyuntingan. Seluruh kekeliruan adalah berasal dari penulis.

\section{DAFTAR PUSTAKA}

\section{Buku}

Banerjee, A. and Watson, T.F. (2011) Pickard's manual of operative dentistry. 9th edn. Oxford: Oxford University Press;

Birnie, Patricia, Alan Boyle dan Catherine Redgwell, (2009). International Law and the Environment. Oxford: Oxford University Press;

Cannizzaro, Enzo. (2015) The Present and Future of Jus Cogens. Roma: Sapienza Università Editrice;

Chen, Lung-Chu. (2015). An Introduction to Contemporary International Law. Oxford: Oxford University Press;

Dupuy, P-M. (2003). L'Unité de l'ordre juridique international: cours général de droit international public. Leiden: Martinus Nijhoff;

Goklany, Indur M. (2001) The Precautionary Principle: a critical appraisal of environment risk assessment. Washington, D.C.: CATO Institute;

Hannikainen, Lauri Antero. (1988) Peremptory Norm (Jus Cogens) in International Law - Historical Development, Criteria, Present Status. Helsinki: Finnish Lawyers' Publishing Co;

Hohmann, H. (1994) Precautionary Legal Duties and Principles of Modern International Environmental Law. London: Graham \& Trotman;

Koskenniemi, Martti. (2011) The Politics of International Law. Oxford: Hart;

Orakhelashvili, Alexander. (2006) Peremptory Norms in International Law. Oxford: Oxford University Press;

Sinclair, I. (1984). The Vienna Convention on the Law of Treaties, 2nd ed. Manchester: Manchester University Press;

Sunstein, Cass S. (2005) Laws of Fear Beyond the Precautionary Principle. UK: Cambridge University Press.

Duvic-Pavoli, Leslie-Anne. (2019) Environmental Law and Public International Law, Dalam: Lees, Emma dan Vinuales Jorge E., eds., Oxford Handbook of Comparative Environmental Law. Oxford: OUP; 
d'Aspremont J. (2016) Jus Cogens as a Social Construct Without Pedigree. Dalam: Heijer M. dan van der Wilt, H. N. eds. Netherlands Yearbook of International Law 2015, vol. 46. The Hague: T.M.C. Asser Press;

Kotzé, Louis J. (2016) Constitutional Conversations in the Anthropocene: In Search of Environmental Jus Cogens Norms. Dalam: Heijer M., van der Wilt H. (eds) Netherlands Yearbook of International Law 2015. Netherlands Yearbook of International Law, vol 46. The Hague.: T.M.C. Asser Press;

Linderfalk, U. (2016) Understanding the Jus Cogens Debate: The Pervasive Influence of Legal Positivism and Legal Idealism. Dalam: Heijer M., van der Wilt H. (eds) Netherlands Yearbook of International Law 2015. Netherlands Yearbook of International Law, vol 46. The Hague.: T.M.C. Asser Press.

\section{Jurnal}

Bodansky, D. (1991). Scientific uncertainty and the Precautionary Principle.

Environment 33 (1991);

Boon, Foo Kim. (1992) The Rio Declaration and its Influence on International Environmental Law. Singapore Journal of Legal Studies December;

Boutillon, Sonia. (2002) The Precautionary Principle: Development of an International Standard. Michigan Journal of International Law 23 (2);

Cameron, J. dan Abouchar, J. (1991). The Precautionary Principle: A Fundamental Principle of Law and Policy for the Protection of Global Environment. Boston College International and Comparative Law Review 14;

Colombo, Esmeralda. (2017) Enforcing International Climate Change Law in Domestic Courts: A New Trend of Cases for Boosting Principle 10 of the Rio Declaration? UCLA Journal of Environmental Law and Policy, 35 (1);

Cross, Frank B. (1995) Paradoxical Perils of the Precautionary Principle. Washington and Lee Law Review 53, no. 3;

Francioni, Francesco. (2016) From Rio to Paris: What is Left of the 1992 Declaration on Environment and Development?. Intercultural Human Rights Law Review 15 (11);

Hardjaloka, Loura. (2012) Ketepatan Hakim dalam Penerapan Precautionary Principle sebagai “Ius Cogen" dalam Kasus Gunung Mandalawangi. Jurnal Yudisial 5, no. 2;

Helmi, et. al. (2019) Documenting Land-combustion and Progressive Law Enforcement in Indonesia. Library Philosophy and Practice; 
Imamulhadi. (2013) Perkembangan Prinsip Strict Liability dan Precautionary dalam Penyelesaian Sengketa Lingkungan Hidup di Pengadilan. Mimbar Hukum 25 (3);

Koskenniemi, Martti. (1997) Hierarchy in International Law: A Sketch, European Journal of International Law;

Luhulima, H. V. (2018) Identifikasi dan Validitas Norma-norma Jus Cogens dalam Hukum Internasional. Justitia et Pax 34 (1);

Mclntyre, Owen dan Mosedale, Thomas. (1997) Precautionary Principle as Customary International Law. Journal of Environmental Law 9(2);

Orellana, Marcos. (2016) Governance and the Sustainable Development Goals: The Increasing Relevance of Access Rights in Principle 10 of the Rio Declaration. RECIEL 25 (1);

Prevost, Denise. (2005) What Role for the Precautionary Principle in WTO Law after JapanApples?. Economic Policy and Law: Journal of Trade E Environmental Studies 2(4);

Sandin, P. (1999). Dimensions of the Precautionary Principle, Human and Ecological Risk Assessment: An International Journal 5;

Saul, Matthew. (2011) The Normative Status of Self-determination in International Law: A Formula for Uncertainty in the Scope and Content of the Right? Human Rights Review;

Shelton, Dinah. (2006) Normative Hierarchy in International Law. American Journal of International Law 100;

Singleton-Cambage, K. (1996). International Legal Sources And Global Environmental Crises: The Inadequacy of Principles, Treaties, and Custom. ILSA Journal of International $\mathcal{E}$ Comparative Law 2;

Sirinskiene, Agne. (2009) The Status of Precautionary Principle: Moving towards a Rule of Customary International Law. Jurisprudencija ,2009;

Tladi, Dire. (2019) Codification, Progressive Development, New Law, Doctrine, and the Work of the International Law Commission on Peremptory Norms of General International Law (Jus Cogens): Personal Reflections of the Special Rapporteur. FIU Law Review 13;

Triatmodjo, Marsudi. (1999) Penerapan Precautionary Principle: Pergeseran Paradigma Hukum Lingkungan Internasional, Mimbar Hukum 6;

Trouwborst, A. (2007). The Precautionary Principle in General International Law: Combating the Babylonian Confusion. Review of European Community \& International Environmental Law 16;

Trouwborst, A. (2009). Prevention, Precaution, Logic and Law: The Relationship between the Precautionary Principle and the Preventative Principle in International Law and 
Associated Questions. Erasmus Law Review 2;

Verdross, A. (1966) Jus Dispositivum and Jus Cogens in International Law.

American Journal of International Law 55;

Verdross, A. (1937) Forbidden Treaties in International Law: Comments on Professor Garner's Report on the 'Law of Treaties.' American Journal of International Law 31;

Wibisana, Andri. (2011) The Development of the Precautionary Principle in International and in Indonesian Environmental Law. Asia Pacific Journal of Environmental Law 14 (1\&2);

Wiener, Jonathan B. \& Rogers, Michael D. (2002) Comparing Precaution in the United States and Europe. Journal of Risk Research 5;

Wirth, David A. (1995) The Rio Declaration on Environment and Development: Two Steps Forward and One Back, or Vice Versa. Georgia Law Review 29.

\section{Peraturan Perundang-Undangan}

Indonesia. (1847) Burgerlijk Wetboek voor Indonesië;

Undang Undang Undang Nomor 23 Tahun 1997 tentang Pengelolaan Lingkungan Hidup.

\section{Dokumen Internasional}

Mahkamah Internasional, (1945) Statuta Mahkamah Internasional. (1995) East Timor (Portugal v. Australia);

(1974) Request for an Examination of the Situation in Accordance with Paragraph 63 of the Court's Judgment of 20 December 1974 in the Nuclear Tests (New Zealand v. France);

(1977). Gabčíkovo-Nagymaros Project (Hungary/Slovakia);

(2002) (Congo v. Rwanda);

(1970) Case Concerning Barcelona Traction, Light, and Power Co., Ltd (Belgium v. Spain);

Perserikatan Bangsa-Bangsa. (1969) Vienna Convention on the Law of Treaties;

(1982) World Charter for Nature;

(1992) The United Nations Framework Convention on Climate Change;

(1992) The Convention on Biological Diversity;

(2000) Cartagena Protocol on Biosafety;

(2016) ILC First report of the Special Rapporteur on Jus Cogens, ILC Report, A/71/10;

(2019) ILC Fourth report on peremptory norms of general international law (jus cogens) by Dire Tladi, Special Rapporteur, A/CN.4/727;

Komisi Eropa (2000) Commission Communication on the Precautionary Principle; 
Lauterpacht, Hersch. (1953), First Report on the Law of Treaties. 24 March 1953 (A/CN.4/63), Yearbook of International Law Commission, Vol. II: 90-162;

Martti Koskenniemi, (2006) Fragmentation of International Law: Difficulties Arising from the Diversification and Expansion of International Law, UNGA A/CN.4/L.682, 13 April 2006;

ITLOS. (1999) Southern Bluefin Tuna (N.Z. v. Japan) (Austl. v Japan);

(2002) The MOX Plant Case (Ireland v. United Kingdom);

Inter-American Commission on Human Rights (1996) Victims of the Tugboat "13 de Marzo" v. Cuba, Case 11.436;

(2002) Juridical Condition and Rights of the Child, Advisory Opinion;

(2003) Juridical Condition and Rights of the Undocumented Migrants;

Ad-Hoc-Award. (1982) Kuwait v. The American Independent Oil Company (AMINOIL);

PCIJ. (1934) The Oscar Chinn Case (Britain v. Belgium);

UNHCR (1982) Conclusion No. 25 (XXXIII-1982);

WTO. (1994) Agreement on Trade-Related Aspects of Intellectual Property Rights.

\section{Putusan Pengadilan}

Mahkamah Agung. Putusan No. 1794K/PDT/2004. Mahkamah Agung. Putusan No. 101 K/TUN/2013. Mahkamah Agung. Putusan No. 04/K/N/HaKI/2005;

Pengadilan Negeri Bandung. Putusan No. 49/Pdt.G/2003/PN.Bdg. Pengadilan Negeri Banjarmasin. Putusan No. 125/Pdt.G/LH/2016/PN Bjm. Pengadilan Negeri Jakarta Pusat;

Putusan No. 06/Merek/2001/PN.Niaga/JKT.PST. Pengadilan Negeri Niaga Jakarta Pusat; Putusan No.14/Merek/2004/PN.Niaga.Jkt.Pst Pengadilan Negeri Niaga Jakarta Pusat; Putusan No.77/Merek/2003/PN.Niaga.Jkt.Pst;

Pengadilan Negeri Jakarta Selatan. Putusan No. 456/Pdt.G-LH/2016/PN Jkt.Sel. Pengadilan Negeri Palangkaraya. Putusan No. 213/Pdt.G/LH/2018/PN Plk;

Pengadilan Negeri Kuala Kapuas. Putusan No. 51/Pdt.Plw-LH/2018/PN Klk Pengadilan Tinggi Bandung. Putusan No. 507/PDT/2003/PT.Bdg;

Pengadilan Tinggi Palembang. Putusan No. 51/PDT/2016/PT.Plg. Amerika Serikat. Court of Appeals (DC). CUSCLIN, 85 ILR 261. 